\title{
The relation between pressure-volume curve traits and stomatal regulation of water potential in five temperate broadleaf tree species
}

\author{
Christoph Leuschner $^{1} \cdot$ Paul Wedde $^{1} \cdot$ Torben Lübbe $^{1}$
}

Received: 19 July 2018 / Accepted: 17 April 2019 / Published online: 5 June 2019

(C) INRA and Springer-Verlag France SAS, part of Springer Nature 2019

\begin{abstract}
- Key message In the five temperate tree species, leaf turgor loss point and the stringency of stomatal regulation are not related to each other and to the drought sensitivity of radial growth, suggesting that additional factors exert a large influence on the species' drought tolerance.

- Context How trees are responding to drought will largely determine their fitness and survival in a warmer and drier world. Much of our understanding of the drought response strategies of woody plants has been based on the study of either plant hydraulics or leaf water status dynamics or stomatal behavior, while the interaction of these components is less often studied.

- Aims To examine the relatedness of leaf tissue osmotic and elastic properties to the isohydry-anisohydry syndrome in adult trees of five co-occurring broadleaf tree species (Acer pseudoplatanus L., Carpinus betulus L., Fagus sylvatica L., Fraxinus excelsior L., and Tilia cordata Mill.), which differ in the stringency of stomatal regulation.

- Methods Adult trees of the five species were accessed with a mobile canopy lift and pressure-volume ( $\mathrm{p}-\mathrm{v})$ curves of sun leaf tissue analyzed for species differences and seasonal change in $\mathrm{p}-\mathrm{v}$ curve parameters. The extent of seasonal fluctuation in daily leaf water potential $\left(\Psi_{1}\right)$ minima served to position the species along the isohydry-anisohydry continuum.

- Results The five species differed greatly in the bulk modulus of elasticity $(\varepsilon)(12 \mathrm{MPa}$ to $33 \mathrm{MPa})$ and, to a lesser extent, in leaf water potential at turgor loss $\left(\pi_{\mathrm{tlp}}\right)(-2.3 \mathrm{MPa}$ to $-2.9 \mathrm{MPa})$, exhibiting species-specific combinations of $\mathrm{p}$-v parameters with the extent of $\Psi_{1}$ fluctuation. However, $\pi_{\text {tlp }}$ and $\varepsilon$ were only weakly, or not at all, related to the species' position along the isohydryanisohydry continuum. Anisohydric Fagus sylvatica with high $\varepsilon$ and relatively low $\pi_{\text {tlp }}$ had a more drought-sensitive radial growth than the fairly isohydric Tilia cordata with low $\varepsilon$ and relatively high $\pi_{\text {tlp }}$.

- Conclusion The five coexisting tree species exhibit largely different drought response strategies, which are partly determined by species differences in leaf tissue elasticity and the stringency of stomatal regulation.
\end{abstract}

Keywords Anisohydry $\cdot$ Acer pseudoplatanus $\cdot$ Carpinus betulus $\cdot$ Fagus sylvatica $\cdot$ Fraxinus excelsior $\cdot$ Isohydry $\cdot \mathrm{p}$-v curve analysis $\cdot$ Tilia cordata

\section{Introduction}

When exposed to water deficits, plants exhibit a variety of response strategies, which include biochemical, physiological, and anatomical adjustments targeted at maintaining metabolic activity under drought stress (Kramer and Boyer 1995; Blum

Handling Editor: Erwin Dreyer

Christoph Leuschner

cleusch@gwdg.de

1 Department of Plant Ecology, University of Goettingen, 37073 Goettingen, Germany
2016). Trees as long-lived organisms are especially vulnerable to water scarcity, and recent reports about climate warmingrelated tree dieback in many regions of the world have triggered growing scientific interest in the drought response of trees (van Mantgem et al. 2009; Lakatos and Molnar 2009; Allen et al. 2010).

Trees can adjust their water consumption and hydraulic safety through the coordination of stomatal regulation and adaptive modification of the hydraulic system (Sperry 2000; Choat et al. 2012; Schuldt et al. 2016). Partial stomatal closure triggered through physical and chemical signals is a shortterm response to water deficits, enabling the plant to avoid turgor loss and critically low water potentials, which may cause hydraulic failure and reduced cell growth rates and, 
eventually, can lead to plant death. Different tree species differ considerably in the stringency of stomatal regulation (Klein 2014; Meinzer et al. 2017), which has implications for balancing carbon gain with water loss. Tardieu and Simonneau (1998) introduced the distinction between isohydric species, which maintain a fairly constant minimum leaf water potential $\left(\Psi_{1}\right)$ through sensitive stomatal regulation, from anisohydric species, which allow marked drops in $\Psi_{1}$ with increasing evaporative demand and decreasing soil water potential $\left(\Psi_{\mathrm{s}}\right)$. Isohydric species have been hypothesized to close stomata earlier during water deficits and, consequently, to depend more on stored carbohydrates to meet continued carbon demands, while anisohydric taxa should be more vulnerable to hydraulic failure, as stomata close later and plants reach more negative xylem water potentials (McDowell et al. 2008; Mitchell et al. 2012; Martinez-Vilalta and GarciaForner 2017). In a certain sense, isohydry/anisohydry relates to the concept of stress avoidance and tolerance introduced by Levitt (1972) in that isohydric species avoid drought strain through strict stomatal control ("water savers") or improved water uptake ("water spenders"), while anisohydric species achieve partial drought tolerance through biochemical and physical adaptations at the leaf and xylem levels. Recent studies with multiple species suggest that isohydry versus anisohydry represents extremes of a continuum of stomatal regulation patterns rather than two opposing strategies, and species may be ranked according to their degree of isohydry-anisohydry (Klein 2014). A similar continuum may exist for the strategies of drought stress avoidance and tolerance.

Besides species differences in stomatal regulation, plants vary largely in the osmotic and elastic properties of leaf tissues (Abrams and Kubiske 1990; Bartlett et al. 2012). Cell turgor is the best recognized indicator of plant drought stress, as it impacts on cell enlargement, cellular structural integrity, photosynthesis, and other metabolic processes (Kramer and Boyer 1995). Consequently, leaf water potential at turgor loss ( $\Psi_{\text {tlp }}$ or $\pi_{\text {tlp }}$ ) has widely been used as a measure of the drought tolerance of plants (Bartlett et al. 2012). Plants with low $\pi_{\text {tlp }}$ tend to maintain stomatal conductance, photosynthesis, hydraulic conductance, and growth at lower $\Psi_{\mathrm{s}}$ than plants with higher $\pi_{\text {tlp }}$ (Mitchell et al. 2008; Blackman et al. 2010). Strategies to cope with seasonal water scarcity at the cellular level are to reduce $\pi_{\text {tlp }}$ through the accumulation of osmotically active compounds in the cell or to alter the elasticity of cell walls in order to maintain turgor (Hsiao 1973; Clifford et al. 1998; Lambers et al. 2008). The existing studies indicate large species differences in the capability of osmotic and elastic adjustment among woody plants (Kozlowski and Pallardy 2002; Sanders and Arndt 2012), but it is not entirely clear how these differences relate to the stomatal control patterns (isohydry-anisohydry).
For a full understanding of the drought response of trees, the relationship between stomatal control of water loss and leaf water potential fluctuation is crucial, as gas exchange and plant hydraulics are tightly coordinated across species, with implications for hydraulic safety and survival during drought (Meinzer 2002; Mencucchini 2003; Brodribb et al. 2014). Numerous studies have investigated the dynamics of leaf water relations and stomatal regulation of temperate tree species with the aim to identify species differences in drought response strategies and to rank the species according to their drought sensitivity (Abrams 1991; Köcher et al. 2009; Meinzer et al. 2014, 2017). However, species rankings may differ in dependence on the trait investigated and the scale considered. Sensitivity rankings based on stomatal regulation, the fluctuation of leaf water potential and turgor, embolism resistance, or the extent of radial growth reductions likely will give different results. The investigation of different ontogenetic stages of a tree further adds to this variation. Most studies on the leaf-level water status and stomatal regulation of woody plants were conducted with seedlings and saplings, the results of which may not be applicable to adult trees. The drought adaptation strategies of adult trees have only rarely been compared among different temperate species that coexist under the same climatic and edaphic conditions; examples are the studies of Abrams (1991), Köcher et al. (2009), and Leuzinger et al. (2005).

Here, we present the results of a comparative study of leaf osmotic and elastic properties and leaf water status dynamics of five temperate broadleaf tree species (Acer pseudoplatanus, Carpinus betulus, Fagus sylvatica, Fraxinus excelsior, and Tilia cordata) growing in a temperate mixed forest. The species are from different families and vary in wood density, canopy architecture, xylem anatomy and hydraulic architecture (diffuse- vs. ring-porous), leaf size and morphology, and mycorrhizal type (ectomycorrhiza (ECM) vs. arbuscular mycorrhiza (AM)), suggesting that they may have developed different drought response strategies (Table 1). In fact, ecophysiological and dendroecological studies demonstrated that the species differ in the stringency of stomatal regulation and the drought sensitivity of growth (Köcher et al. 2009; Zimmermann et al. 2015). According to stomatal conductance measurements, the five species occupy different positions along the isohydryanisohydry continuum (Köcher et al. 2009).

Against this background, we analyze pressure-volume ( $\mathrm{p}$ v) curves from sun canopy leaves of adult trees, using a mobile canopy lift. To characterize the species' drought response strategy, we not only refer to the stomatal regulation behavior (isohydry-anisohydry) but also use the extent of droughtinduced reduction in radial growth for assessment. By relating $\mathrm{p}-\mathrm{v}$ curve parameters and their seasonal variation to the species' drought response strategy, we test the statement of Bartlett et al. (2012) that $\pi_{\text {tlp }}$ is the trait quantifying the species' drought tolerance most directly. We address three main research questions: (i) Do the co-occurring species differ in p- 
Table 1 Functional and morphological traits of the five studied tree species according to Bartels (1993), Hölscher et al. (2002), Köcher et al. (2009), and Ellenberg and Leuschner (2010)

\begin{tabular}{|c|c|c|c|c|c|}
\hline & Fraxinus excelsior & Acer pseudoplatanus & Carpinus betulus & Tilia cordata & Fagus sylvatica \\
\hline Family & Oleaceae & Sapindaceae & Betulaceae & Malvaceae & Fagaceae \\
\hline Successional status & Early/mid & Mid/late & Mid/late & Mid/late & Late \\
\hline Wood density $\left(\mathrm{kg} \mathrm{m}^{-3}\right)$ & 650 & 590 & 790 & 490 & 680 \\
\hline $\mathrm{DBH}(\mathrm{cm})$ & $35.2-41.2$ & $38.6-76.4$ & $35.3-51.9$ & $41.3-62.9$ & $40.8-50.4$ \\
\hline Tree height (m) & $26.9-28.1$ & $26.8-33.7$ & $24.7-27.9$ & $24.3-31.7$ & $28.2-32.1$ \\
\hline Minimum light demand of shade leaves ${ }^{1}$ & 10 & 5 & 2.5 & 3 & $<1$ \\
\hline SLA $\left(\mathrm{cm}^{2} \mathrm{~g}^{-1}\right)^{2}$ & 144 & 164 & 229 & 291 & 184 \\
\hline Stomatal regulation pattern ${ }^{3}$ & Anisohydric & Isohydric & Isohydric to anisohydric & Fairly isohydric & Anisohydric \\
\hline Drought sensitivity of radial growth ${ }^{4}$ & 5 & 2 & 4 & 3 & 1 \\
\hline Type of mycorrhiza & $\mathrm{AM}$ & $\mathrm{AM}$ & $\mathrm{ECM}$ & ECM & $\mathrm{ECM}$ \\
\hline Xylem anatomy ${ }^{5}$ & Ring & Diffuse & Diffuse & Diffuse & Diffuse \\
\hline$n$ (trees) & 3 & 3 & 4 & 3 & 4 \\
\hline
\end{tabular}

The number of tree individuals sampled and biometric data (DBH, tree height) of these trees are also given

$A M$ vesicular-arbuscular mycorrhiza, ECM ectomycorrhiza

${ }^{1}$ Light intensity at the height of the lowest shade leaves relative to incident light intensity according to Leuschner and Ellenberg (2017)

${ }^{2}$ Sun leaves (after Leuschner and Ellenberg 2017)

${ }^{3}$ Species' position along the isohydry - anisohydry continuum according to seasonal leaf water potential variability as depicted in Fig. 2

${ }^{4}$ Species ranking of drought sensitivity according to dendrochronological data from the Hainich forest and other mixed forests in Central Germany after Frech (unpublished) and Zimmermann et al. (2015) (1, most sensitive; 5, least sensitive)

${ }^{5}$ Ring-porous, diffuse-porous

$\mathrm{v}$ parameters in relation to their water use strategy and drought sensitivity of growth? (ii) Is there seasonal variation in osmotic and elastic traits that assists the drought tolerance strategy? (iii) What are the species-specific strategies to tolerate drought?

\section{Materials and methods}

\subsection{Study site and tree species}

The study was carried out in summer 2009 in a temperate mixed deciduous broadleaf forest in the Hainich National Park (7610 ha), located in western Thuringia, Central Germany $\left(51^{\circ} 04^{\prime} \mathrm{N}, 10^{\circ} 30^{\prime} \mathrm{E}\right)$. The Hainich forest is one of the largest non-fragmented broad-leaved forests of Central Europe (Hiekel et al. 2004), which, in many parts, has been managed through an extensive selection cutting system, resulting in a relatively natural forest structure and a high tree species richness for Central European standards. The mean annual precipitation of the study region is $590 \mathrm{~mm}$, and the mean annual temperature is $7.5{ }^{\circ} \mathrm{C}(1973-2004)$ (Deutscher Wetterdienst 2005). Partly stagnic Luvisols are the dominant soil type that developed in Pleistocene loess on Triassic limestone as bedrock (Guckland et al. 2009).

Five widespread tree species from different families were chosen for the study of leaf water status and pressure-volume curve parameters in the canopy of adult trees, i.e., sycamore maple (Acer pseudoplatanus L.), European beech (Fagus sylvatica L.), European ash (Fraxinus excelsior L.), European hornbeam (Carpinus betulus L.), and little-leaf linden (Tilia cordata Mill.). All mentioned species reach $>10 \%$ cover in the Hainich mixed forest. During the summer of 2009 , leaf and shoot samples were taken from each three to four individuals per species, which grew together in a forest patch of ca. 0.5 ha. Data on the drought sensitivity of radial growth of Zimmermann et al. (2015) point at a decreasing drought tolerance in the sequence $F$. excelsior $>C$. betulus $>$ T. cordata $>$ A. pseudoplatanus $>$ F. sylvatica. The five species also differ with respect to mycorrhiza type (three ECM vs. two AM species), xylem anatomy (four diffuse-porous vs. one ring-porous species), and wood density (490-790 $\mathrm{kg} \mathrm{m}^{-3}$ ), traits with potential influence on tree water relations (Table 1). Thus, the coexisting species in the Hainich mixed forest represent largely different tree functional types.

We selected dominant trees reaching the upper canopy (24.3-33.7 $\mathrm{m}$ in height, Table 1), which grew at a maximum distance of $100 \mathrm{~m}$ to each other. From tree ring data and forest history records, the age of the trees is estimated to be 80 120 years (Gebauer et al. 2008). To access sun canopy branches and leaves, we used a mobile lift (model DL30; Denka-Lift AS, Denmark) that reaches a maximum height of $30 \mathrm{~m}$ and can move on forest access tracks. This allowed accessing the sun canopy of 17 tree individuals of different species in due time. 


\subsection{Climate variables and soil hydrological measurements}

Air relative humidity $(\mathrm{RH})$ and air temperature $(T)$ were monitored in the upper canopy of the stand (ca. $2 \mathrm{~m}$ below the canopy surface) with a Rotronic temperature and humidity probe (MP100A Hygromer; Rotronic, Ettlingen, Germany). Measurements were taken every $30 \mathrm{~s}$ with a Campbell CR1000 data logger (Campbell Scientific Ltd., Cambridge, UK) and stored as half-hourly means. Hourly values of global radiation $(I)$ and precipitation $(P)$ were obtained from the nearby $(2 \mathrm{~km})$ Weberstedt/Hainich meteorological station (Meteomedia $\mathrm{GmbH}$ ).

Volumetric soil water content $(\Theta)$ was recorded two times a day (0000 hours and 1200 hours) with time domain reflectometry probes (CS616 Water Content Reflectometer; Campbell Scientific Ltd., Cambridge, UK) installed at three soil depths $(10 \mathrm{~cm}, 30 \mathrm{~cm}$, and $50 \mathrm{~cm})$ in a soil pit close to the 17 trees. Soil matrix potential $\left(\Psi_{\mathrm{s}}\right)$ was calculated with the program Rosetta Lite (version 1.2) (Schaap et al. 1998) from the soil water content data at $10 \mathrm{~cm}$ soil depth, using information on the grain size distribution of the soil. For further measuring details, see Köcher et al. (2012a).

\subsection{Establishment of pressure-volume curves}

Pressure-volume curves were established on three occasions during the vegetation period between early June and late September 2009, using a pressure chamber (M600; PMS Instrument Company, Albany, USA) applying the overpressurization technique (Tyree and Jarvis 1982). The first sampling period (June 6-July 1) was in a moist early summer period; the second (July 24-August 5), during a longer midsummer dry spell; and the third (September 15-21), in a moist late summer period. The different individuals of a species were sampled in a rotating scheme, so that the species were measured roughly at the same time. On each occasion, five to six exposed, terminal leaves or shoots from the sun canopy (i.e., one to two samples per tree) were collected from three or four different trees per species that were similar in diameter and height (for the number of replicate trees, see Table 1). The leaves of $C$. betulus, T. cordata, and F. sylvatica had too short petioles for being inserted into the pressure chamber; we alternatively measured small terminal shoots in these species. In case of F. excelsior, the whole compound leaf was measured. Following the protocol given by Koide et al. (2000) and Prometheuswiki (2018), the leaves or shoots were collected during the afternoon, wrapped in plastic bags and brought to the laboratory, re-cut under water, and hydrated to nearmaximum turgor in tap water, while kept cool in the dark. Care was taken to prevent leaf oversaturation by detecting eventual water outflow form the sample, when water potential was equal to zero (Kubiske and Abrams 1991). On the next day, the samples were either processed or kept cool at $6{ }^{\circ} \mathrm{C}$ until being processed within $72 \mathrm{~h}$. Up to four pressure-volume curves were generated simultaneously using four pressure chambers in parallel.

To determine initial fresh weight, samples were re-cut again, dried with tissue paper, weighed to $1 \mu \mathrm{g}$, and immediately placed in the pressure chamber to measure the initial water potential. The chamber was lined with moist cloth to reduce evaporative water losses. The pressure in the chamber was then increased to $0.4 \mathrm{MPa}$ and kept at this level for $10 \mathrm{~min}$, while the expressed sap was collected in a small vial filled with cotton wool. Subsequently, the pressure was released to allow symplast and apoplast to equilibrate again for $10 \mathrm{~min}$. This procedure was repeated in pressure steps of 0.3 MPa until 2.5 MPa was reached. Between 2.5 and $3.3 \mathrm{MPa}$ (final value), the steps were reduced to $0.2 \mathrm{MPa}$ to achieve a higher resolution in the linear part of the pressure-volume curve. To calculate the amount of expressed sap, the vials were weighed with an accuracy of $0.1 \mathrm{mg}$ before and after collecting the sap. Finally, leaves and shoots were dried at $70{ }^{\circ} \mathrm{C}$ for $48 \mathrm{~h}$ to determine dry weight.

The following parameters were derived from the pressure-volume curves (plot of water potential $(-1 / \Psi$ in $\mathrm{MPa}$ ) vs. 100 - total relative water content (RWC, in \%)) (Koide et al. 2000): osmotic potential at full turgor $\left(\pi_{0}\right)$ and at turgor loss point $\left(\pi_{\text {tlp }}\right)$, relative water content (symplastic water) at full hydration $\left(\mathrm{RWC}_{0}\right)$, relative water content at turgor loss point $\left(\mathrm{RWC}_{\mathrm{tlp}}\right)$, symplastic water fraction (SWF) at full turgor, the bulk modulus of tissue elasticity $\left(\varepsilon_{0}\right)$, and relative capacitance at full turgor $\left(C_{0}\right) . \pi_{0}$ is the osmotic potential at $100-\mathrm{RWC}=0, \pi_{\text {tlp }}$ is the osmotic potential at which turgor $\left(\Psi_{\mathrm{P}}\right)$ is zero and bulk leaf water potential is equal to osmotic potential, $\mathrm{RWC}_{0}$ is the saturation water content, and $\mathrm{RWC}_{\mathrm{tlp}}$ is the relative water content at which bulk leaf water potential is equal to osmotic potential. $\mathrm{RWC}_{\text {tlp }}$ was estimated by regression analysis using maximum $r^{2}$ as a criterion. $\varepsilon_{0}$ is obtained from the quotient $\Delta \Psi_{\mathrm{P}} /$ $\triangle \mathrm{RWC}$, measured for the first data points, starting with full turgor and calculated for symplastic water content; $C_{0}$ is calculated as $\Delta \mathrm{RWC} / \Delta \Psi$ between full turgor and turgor loss point. For calculating $\varepsilon_{0}$, standard major axes were used (Sokal and Rohlf 1995). Saturation water content gives the mass of water per leaf dry mass $\left(\mathrm{g} \mathrm{g}^{-1}\right)$ at full saturation (full turgor); the symplastic water fraction at full turgor is the proportion of symplastic water in total water at saturation (i.e., 1 - apoplastic water fraction).

\subsection{Leaf water potential measurement}

For relating the $\mathrm{p}-\mathrm{v}$ curve parameters to leaf water potential data measured under field conditions in the adult trees, we used the extensive data set collected by Köcher et al. (2012b) in this stand during summer 2008. On three occasions 
in summer 2008 (early July, early August, mid-September), daily leaf water potential minima $\left(\Psi_{\min }\right)$ were derived for the five species from pressure chamber (M600; PMS Instrument Company, Albany, USA) measurements conducted between 1100 hours and 1400 hours in sun canopy leaves or shoots using the canopy lift. Per measuring date, five to six trees per species with each four samples per tree were investigated. We sampled the same trees that were used for $\mathrm{p}-\mathrm{v}$ curve analysis, plus additional trees in the neighborhood. For further methodological details, see Köcher et al. (2012b). A corresponding measuring campaign had been conducted in the drier summer of 2006. Unfortunately, we were unable to collect $\Psi_{\min }$ data in 2009 during the intensive $\mathrm{p}-\mathrm{v}$ measuring campaign.

\subsection{Statistical analysis}

We used the individual trees as statistical units (p-v curves: $n=4$ trees for $C$. betulus and F. sylvatica and $n=3$ for the other species; leaf water potential measurement: five to six trees per species), while leaf and branch samples collected on the same tree were considered as pseudo-replicates (one to four samples per tree). Regression analyses between soil and leaf water potentials were performed with the program Xact 7.20g (Scilab GmbH, Hamburg, Germany). The R software environment (version 3.3.3; R Core Team, 2017) was used for all other statistical analyses. Linear mixed effects models were calculated for comparing $p-v$ curve traits among the species using the lme() function of the package nlme (Pinheiro et al. 2018). In these runs, we introduced the replicate tree individuals of a species and seasonality as random factors and used a nested design to include replicate measurements on the tree level to account for pseudo-replication. To test for seasonal differences in $\mathrm{p}-\mathrm{v}$ curve traits, we run lme models separately for the five species using sampling date as a fixed effect factor and tree individual as a single random factor. The conditional residuals of all models were examined for normal distribution and homogeneity of variances using diagnostic plots. In case of discernable heteroscedasticity, lme models were adjusted by incorporating a weighted identity variance structure related to the fixed factor (VarIdent) as recommended by Zuur et al. (2009) to satisfy the model assumptions. Multiple comparisons of means among species or sampling dates per species were carried out post hoc using Tukey's HSD tests by applying the $g l h t()$ function of the package multcomp. Ranktransformed seasonal means of $\mathrm{RWC}_{\mathrm{tlp}}, \varepsilon$, and $\Psi_{\text {tlp }}$ and seasonal minima of leaf water potential $\left(\Psi_{\min }\right)$ were correlated against each other and against the drought tolerance ranking and the isohydric-anisohydric behavior (expressed in categories 1 to 5) of the five species using the Spearman rank correlation.

\section{Results}

\subsection{Weather and soil moisture conditions}

The summer 2009 received average rainfall amounts without severe dry periods, but moderate soil water deficits in late summer. Between the end of July and September 12, less than $80 \mathrm{~mm}$ of rain was recorded and topsoil moisture decreased toward $\Psi_{\mathrm{s}}$ minima of about $-0.14 \mathrm{MPa}$, indicating moderate topsoil desiccation in this period (Fig. 1). Maxima of daily mean temperature reached $22{ }^{\circ} \mathrm{C}$ in late August, when peak atmospheric saturation deficits of $2 \mathrm{kPa}$ (daily mean) were reached in the upper canopy.

\subsection{Leaf water potential fluctuation}

According to measurements in the canopy in the moist summer of 2008, diurnal minima of sun leaf water potential $\left(\Psi_{\min }\right)$ differed among the five species with respect to absolute height and seasonal amplitude. Lowest minima $(<-3.0 \mathrm{MPa})$ and, by far, the largest seasonal variation in $\Psi_{\min }$ were recorded in the ringporous species $F$. excelsior, while $A$. pseudoplatanus exhibited a remarkably stable leaf water potential with daily minima always above-1.0 MPa (Fig. 2). F. sylvatica also reached low potential minima $(<-2.5 \mathrm{MPa})$ in drier periods but maintained relatively low $\Psi_{\min }$ in moist periods as well (always $<-1.4 \mathrm{MPa}$ ). The $\Psi_{\min }$ range of $C$. betulus and $T$. cordata was intermediate between that of F. sylvatica and that of A. pseudoplatanus, but $C$. betulus regularly reached lower $\Psi_{\min }$ values in dry periods than $T$. cordata. From the seasonal variation in $\Psi_{\mathrm{L}}$, we considered $F$. excelsior and F. sylvatica to be anisohydric species, $C$. betulus as following an intermediate strategy between isoand anisohydric, T. cordata as being fairly isohydric, and A. pseudoplatanus to be an isohydric species at this site. A significant positive relationship between $\Psi_{\min }$ and $\Psi_{\mathrm{s}}$ was only observed in F. sylvatica, while F. excelsior, C. betulus, and T. cordata showed no relation and A. pseudoplatanus even a negative one (Fig. 2). Measurements in the drier summer 2006 showed similar species differences in the seasonal $\Psi_{\min }$ variation as in 2008 (Fig. 2), but A. pseudoplatanus reached lower $\Psi_{\min }$ values in this summer.

\subsection{Pressure-volume curve parameters}

The osmotic potential at full turgor $\left(\pi_{0}\right)$ was highest (least negative) in T. cordata (seasonal mean $-1.5 \mathrm{MPa}$ ), intermediate in A. pseudoplatanus $(-1.7 \mathrm{MPa})$, and lowest in F. sylvatica, C. betulus, and F. excelsior ( -1.9 to -2.1 ; Fig. 3a). The osmotic potential at turgor loss point $\left(\pi_{\text {tlp }}\right)$ was highest in A. pseudoplatanus and T. cordata $(-2.2$ and -2.3$)$, intermediate in F. sylvatica $(-2.6)$, and lowest in C. betulus and F. excelsior ( -2.7 and -2.9 ; Fig. 3b). The seasonal change in $\pi_{\text {tlp }}$ and $\pi_{0}$ ranged between 0.1 and 


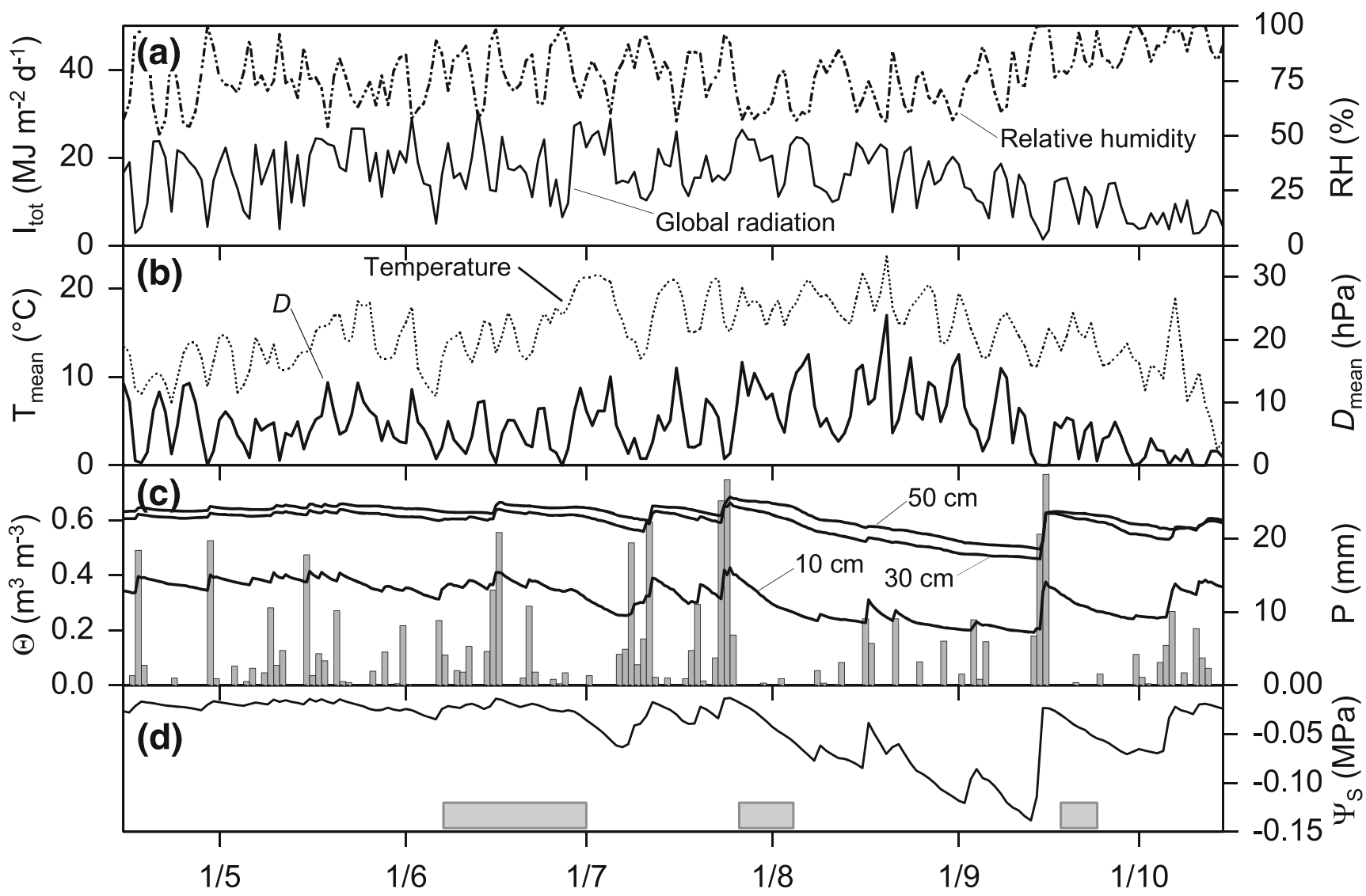

Date

Fig. 1 a Seasonal course of mean daily relative air humidity $\left(\mathrm{RH}_{\text {mean }}\right)$ and daily totals of global radiation $\left(I_{\text {tot }}\right)$. b Daily mean air temperature $\left(T_{\text {mean }}\right)$ and daily mean vapor pressure deficit $\left(D_{\text {mean }}\right)$. c Soil water content $(\Theta)$ at three soil depths $(10 \mathrm{~cm}, 30 \mathrm{~cm}, 50 \mathrm{~cm})$ and daily

0.5 $\mathrm{MPa}$ in all species, with three species showing a significant decrease from June/July to August or September precipitation $(P)$. d Soil matrix potential $\left(\Psi_{\mathrm{s}}\right)$ at $10 \mathrm{~cm}$ soil depth in summer 2009 in the Hainich forest. The gray bars at the figure bottom show the periods of $\mathrm{p}-\mathrm{v}$ curve analysis

(T. cordata, F. sylvatica, and $F$. excelsior), one species revealing no change $(C$. betulus) and another one an increase
Fig. 2 Daily means of midday leaf water potential $\left(\Psi_{\mathrm{L}}\right)$ in relation to the soil matrix potential $\left(\Psi_{\mathrm{s}}\right)$ at $10 \mathrm{~cm}$ depth in the five tree species in summer 2006 and summer 2008. The number of replicates in 2006 is one to two trees per species with four samples per tree, and that in 2008 is four to six trees per species with four samples per tree. For significant relationships including all values (2006 and 2008), the coefficient of determination $\left(r^{2}\right)$ and the $p$ value are given

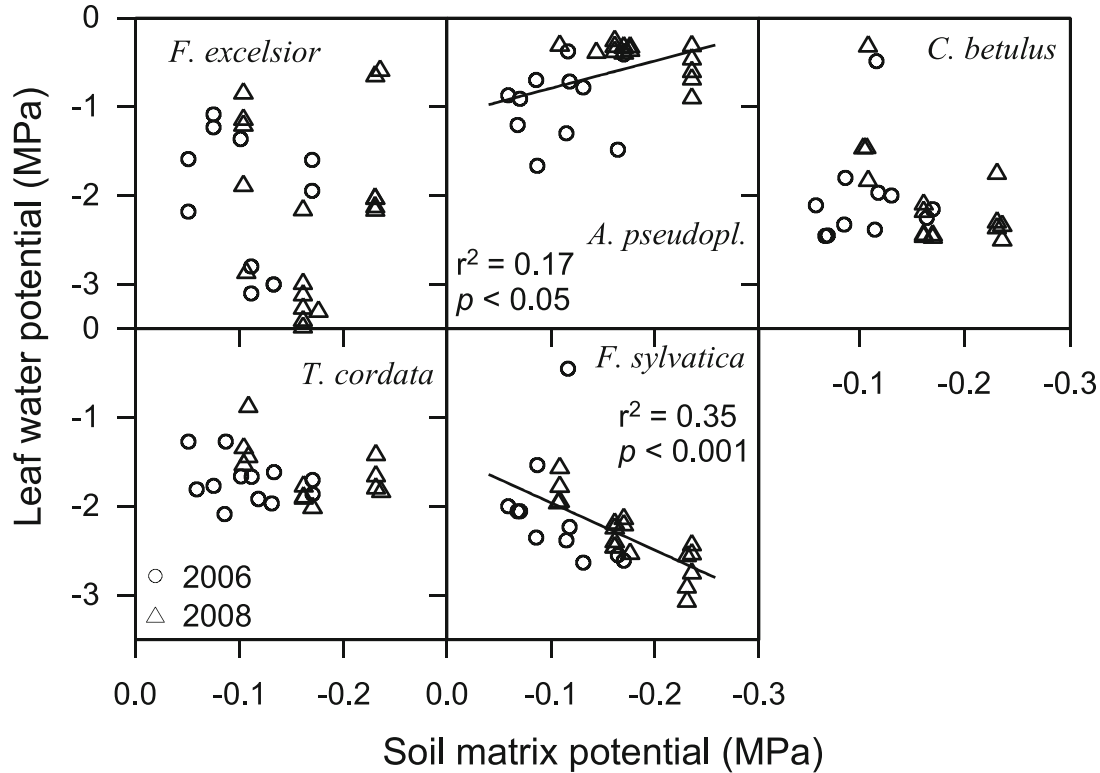


a

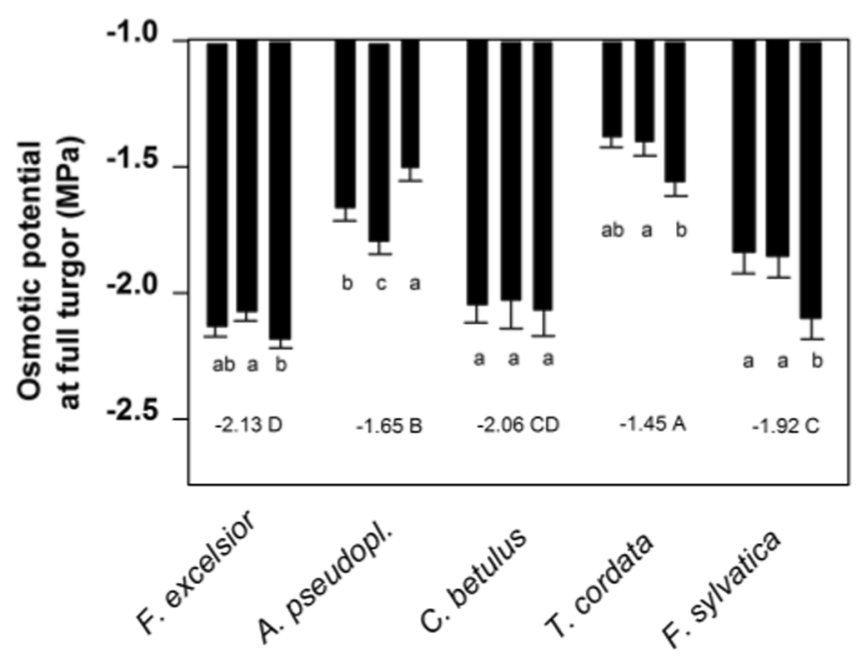

b

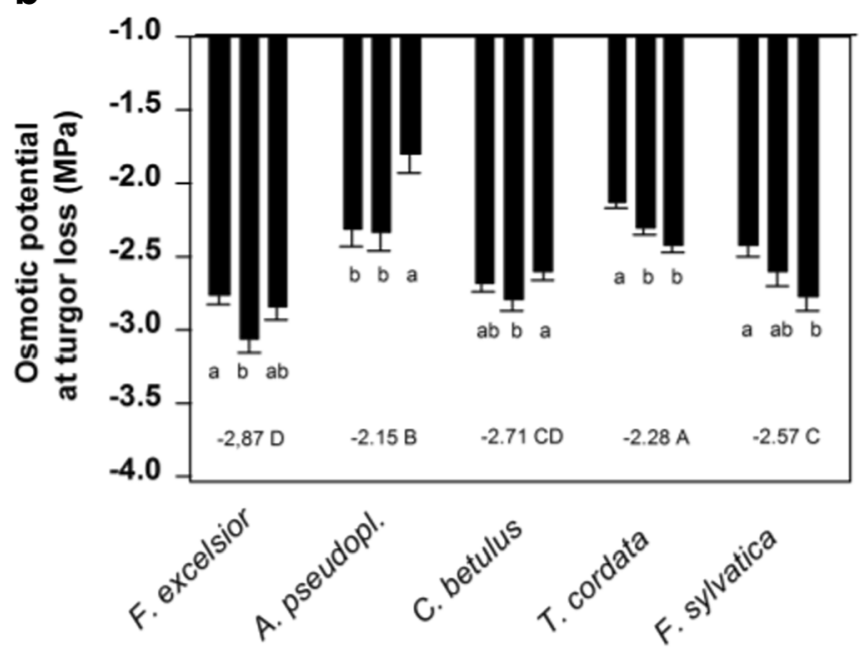

Fig. 3 Osmotic potential $\mathbf{a}$ at full turgor $\left(\pi_{0}\right)$ and $\mathbf{b}$ at the turgor loss point $\left(\pi_{\text {tlp }}\right)$ of sun canopy leaves in the five studied tree species in June/July, August, and September. $\mathbf{c}$ Bulk tissue modulus of elasticity at full turgor $\left(\varepsilon_{0}\right)$. d Relative capacitance of sun canopy leaves in the five studied tree species in June/July, August, and September. $\varepsilon_{0}$ was calculated for the symplastic water content according to Koide et al. (2000). Each bar

(A. pseudoplatanus). Larger species differences than for $\pi_{\text {tlp }}$ were found for the bulk elastic modulus at maximum turgor $\left(\varepsilon_{0}\right)$ (Fig. 3). Lowest values were measured in sun leaves of T. cordata, indicating cell walls with moderate elasticity (ca. $10 \mathrm{MPa}$ ), while $F$. excelsior and A. pseudoplatanus (about $20 \mathrm{MPa}$ ) and $C$. betulus (28 MPa) had significantly higher $\varepsilon_{0}$ values. The stiffest cell walls $\left(\varepsilon_{0}>30 \mathrm{MPa}\right)$ were found in $F$. sylvatica. All species showed tendencies for a $\varepsilon_{0}$ increase by 3-10 MPa from June/July to August or September (significant in $F$. excelsior and A. pseudoplatanus). In correspondence, the relative capacitance $\left(C_{0}\right)$ ranged between 0.06 and $0.10 \mathrm{MPa}^{-1}$ in all species except for $T$. cordata with its much more elastic leaves (0.17-0.23; Fig. 3d).

According to the Spearman rank correlation analysis, $\Psi_{\min }$ was significantly correlated with $\pi_{\text {tlp }}$ across the species sample
C
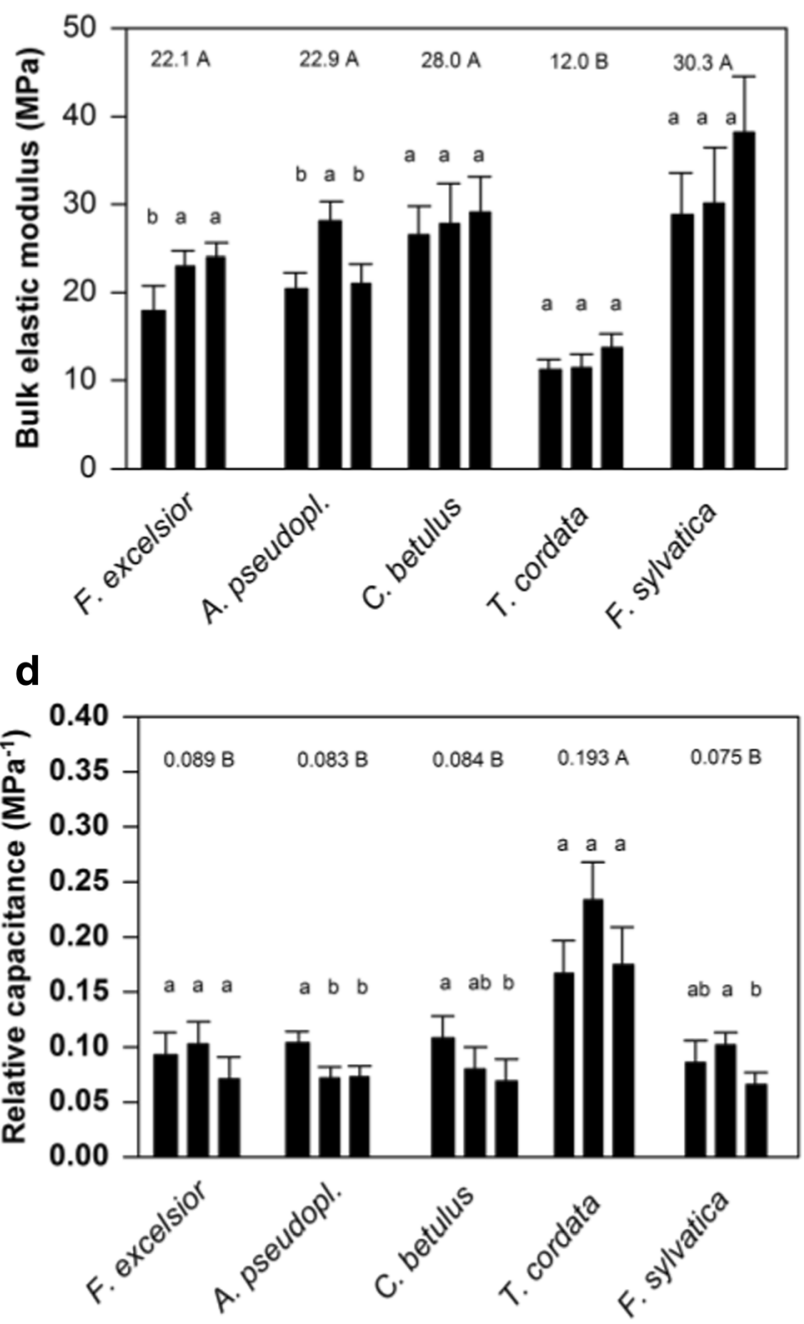

represents the mean value $\pm \mathrm{SE}$ of three to four tree individuals per species. The numbers indicate the mean values of each species over all dates. Different small letters indicate significant differences between periods (June/July, August, and September), and different capital letters indicate significant differences between tree species averages over the growing season $(p<0.05)$

$(p=0.018$; Table 2). Further, species with a more anisohydric behavior tended to display lower $\pi_{\text {tlp }}(p=0.09)$ and higher $\mathrm{RWC}_{\text {tlp }}(p=0.054)$. However, neither $\pi_{\text {tlp }}$ nor $\mathrm{RWC}_{\text {tlp }}$ or $\Psi_{\text {min }}$ was significantly related to the drought tolerance ranking of the species as derived from radial growth. No relation existed between $\pi_{\text {tlp }}$ and $\varepsilon(p=0.87)$.

Leaf tissue water content at full turgor (saturation water content) was highest in its growing season mean (June-September 2009) in F. excelsior and T. cordata and lowest in C. betulus (Fig. 4a in the Appendix). Relative water content at turgor loss point $\left(\mathrm{RWC}_{\mathrm{tlp}}\right)$ was lowest in $T$. cordata (mean of vegetation period $=0.81$ ); reached intermediate values in F. excelsior, A. pseudoplatanus, and C. betulus (0.85-0.86); and was highest in F. sylvatica (0.89; Fig. $4 \mathrm{~b})$. $\mathrm{RWC}_{\text {tlp }}$ increased from June to September by $3-9 \%$ in all species except in T. cordata (Fig. 5). 
Table 2 Correlation matrix for four physiological traits (relative water content at turgor loss point, osmotic potential at turgor loss point, bulk elastic modulus, and recorded minimum leaf water potential; means over all measurements) and the drought sensitivity of radial growth and the stomatal regulation patterns observed in the five species

\begin{tabular}{|c|c|c|c|c|c|c|}
\hline & $\mathrm{RWC}_{\mathrm{tlp}}$ & $\Psi_{\text {tlp }}$ & $\varepsilon$ & $\Psi_{\min }$ & $\begin{array}{l}\text { Stomatal regulation } \\
\text { pattern }\end{array}$ & $\begin{array}{l}\text { Drought sensitivity } \\
\text { of growth }\end{array}$ \\
\hline $\mathrm{RWC}_{\text {tlp }}$ & & $-0.60(0.28)$ & $-0.70(0.19)$ & $-0.80(0.10)$ & $0.87(0.05)$ & $0.10(0.87)$ \\
\hline$\Psi_{\text {tlp }}$ & & & $0.10(0.87)$ & $0.90(0.038)$ & $-0.82(0.09)$ & $-0.70(0.19)$ \\
\hline$\varepsilon$ & & & & $0.20(0.75)$ & $0.36(0.55)$ & $-0.50(0.39)$ \\
\hline$\Psi_{\min }$ & & & & & $-0.98(<0.01)$ & $-0.40(0.50)$ \\
\hline Stomatal regulation pattern & & & & & & $0.21(0.74)$ \\
\hline Drought sensitivity of growth & & & & & & \\
\hline
\end{tabular}

Species ranking of the drought sensitivity of growth according to dendrochronological data from the Hainich forest and other mixed forests in Central Germany after A. Frech (unpublished) and Zimmermann et al. (2015) (1, most sensitive; 5, least sensitive), position along the isohydry-anisohydry continuum as indicated by cardinal values ( 1 , isohydric; 2 , fairly isohydric; 3 , isohydric to anisohydric; 4 , fairly anisohydric; 5 , anisohydric). Given are the Spearman rank correlation coefficient and the probability of error (in parentheses; two-tailored). Significant $(p<0.05)$ relationships are in bold, and marginally significant relationships $(0.1>p \geq 0.05)$ are in italics

Symplastic water fraction reached the highest growing season mean in A. pseudoplatanus (0.7); intermediate mean values in F. excelsior, C. betulus, and T. cordata; and the lowest mean in F. sylvatica (0.45); seasonal variation was large in F. excelsior, but not in the other species (Fig. 4c).

\section{Discussion}

Our results demonstrate considerable species differences in $\mathrm{p}$ $\mathrm{v}$ curve parameters among the five tree species from different families, even though they coexist in the same community under similar hydrologic and climatic conditions. This may indicate that alternative drought tolerance strategies have developed in response to similar climate conditions, or it could reflect responses of the species' ancestors to contrasting evolutionary and environmental drivers other than recent drought exposure, such as past climatic conditions, nutrient availability, or herbivory.

The explicit focus on adult trees distinguishes this study from many earlier investigations on the leaf water status dynamics of temperate trees, which mostly examined seedlings or saplings. Many plant traits change markedly during tree ontogeny, among them rooting depth, fine root system size, hydraulic efficiency in the root-to-leaf pathway, and plant internal water storage (Leuschner and Meier 2018). Stand microclimate as an external determinant of plant water status is also different. Juvenile and adult trees thus are exposed to contrasting moisture regimes in soil and atmospheric and, consequently, should regulate leaf water relations differentially (Kramer and Boyer 1995; Cavender-Bares and Bazzaz 2000). Simple extrapolation of leaf water status data from seedlings or saplings to adult trees may not be possible, as is shown for this species sample by the sapling study of Lübbe et al. (2017).

\subsection{Species differences in p-v curve parameters in relation to isohydry/anisohydry and growth responses}

The largest absolute species differences were found for $\varepsilon$, which differed about threefold (ca. $10 \mathrm{MPa}$ vs. $30 \mathrm{MPa}$ ) between $T$. cordata with elastic cell walls and $F$. sylvatica with stiff walls. However, $\varepsilon$ was neither related to the stomatal control nor related to the drought sensitivity of radial growth in our species sample. The species differences in $\pi_{\text {tlp }}$ were less pronounced than those in $\varepsilon$ (species means: about -2.0 to $-3.0 \mathrm{MPa})$. Nevertheless, anisohydric species tended to have lower $\pi_{\text {tlp }}$ than isohydric species $(r=-0.82, p=0.09)$. In accordance with expectation, anisohydric $F$. excelsior and $F$. sylvatica had the lowest $\pi_{\text {tlp }}$, while isohydric A. pseudoplatanus had the highest. This relates to the observed $\Psi_{\min }$ values and matches the assumed alignment of isohydric species with a drought avoiding, and anisohydric species rather with a tolerating strategy. However, $\pi_{\text {tlp }}$ was not related to the drought sensitivity of growth of the species: taxa with particularly low $\pi_{\text {tlp }}$ were either very sensitive ( $F$. sylvatica) or insensitive (F. excelsior) to water deficits in their long-term growth record (Zimmermann et al. 2015). The high turgor loss point of A. pseudoplatanus $(\sim-2.2 \mathrm{MPa})$ is in accordance with the assumed relatively high drought sensitivity of this species. However, the high $\pi_{\text {tlp }}$ of $T$. cordata does not fully match with the only moderate drought sensitivity of growth of this species, suggesting a water-spending avoidance strategy (Ellenberg 1996; Aasamaa et al. 2004; Köcher et al. 2009; Leuschner and Ellenberg 2017). It appears that neither the isohydry/anisohydry concept nor the assignment of species to drought avoiders/tolerators and water spenders/savers is necessarily linked to the growth performance at water deficits, i.e., tree fitness under stress. 


\subsection{Seasonal variation in osmotic and elastic properties}

Our measurements were conducted in a normal summer with a moist early growing season and shorter rainless periods later in summer, when topsoil $\Psi_{\mathrm{s}}$ dropped to moderate minima of $0.14 \mathrm{MPa}$ in the first half of September, and the atmospheric water vapor saturation deficit reached maxima of $2 \mathrm{kPa}$. Since the soil water potential minima observed in summer 2009 were in the range of values recorded in summer 2006 and summer 2008 ( $-1 \mathrm{MPa}$ to $-5 \mathrm{MPa})$, when considerable leaf water potential drops were recorded, it can be concluded that the trees were exposed to moderate drought stress in later summer 2009 (August/early September), though to a lower extent than in the very dry summer periods of 1976, 2003 (Bréda et al. 2006), and 2018.

Osmotic and elastic adjustment may represent alternative, non-exclusive strategies of plants to maintain turgor and thus to reduce or avoid desiccation-induced strain in the plant (Kramer and Boyer 1995; Pallardy 2008; Blum 2016). The capability for osmotic adjustment in response to water deficits can differ largely between closely related tree species (Kozlowski and Pallardy 2002; Ngugi et al. 2003; Lenz et al. 2006), and it seems to vary considerably among coexisting tree species in the same community. In a global data set of woody and herbaceous plants, Bartlett et al. (2012) found a mean drought-induced reduction in $\pi_{\text {tlp }}$ of $0.44 \mathrm{MPa}$. In our study, increasing water deficits in soil and atmosphere from late July to early September were associated with a decrease in sun leaf $\pi_{\text {tlp }}$ by $0.3-0.4 \mathrm{MPa}$ in three of the five studied species (F. sylvatica, T. cordata, and F. excelsior), which is close to the cited global mean value. The coincidence of the $\pi_{\text {tlp }}$ reduction with the $\Psi_{\mathrm{s}}$ minimum suggests that the observed increase in solute concentration may represent active osmotic adjustment in the three species, even though the absolute degree of osmotic change is actually rather small.

The increase in the bulk modulus of elasticity by $3-10 \mathrm{MPa}$ from late June to September could be acclimation to the dry spell in August/early September 2009, but it may well be mostly a consequence of leaf aging, especially as the $\varepsilon$ change was often insignificant.

Both increases and decreases in $\varepsilon$ have been explained as an adaptive change to drought stress (Schulte 1992), but the physiological significance of seasonal elastic adjustment is interpreted in controversial ways. Bartlett et al. (2012) conclude from a global $\mathrm{p}-\mathrm{v}$ data set and theoretical considerations that variation in $\varepsilon$ has little influence on the turgor loss point and thus the drought tolerance under most environmental conditions encountered by plants (except in cases of low $\pi_{0}$ and low $\varepsilon$ ). In contrast, many field studies with tree seedlings or shrubs considered elastic adjustment as an alternative and often equally important drought acclimation strategy in comparison with osmotic adjustment (Khalil and Grace 1992; Fan et al. 1994; Lambers et al.
2008; Mitchell et al. 2008). An increase in $\varepsilon$ leads to stiffer cell walls, which results in a greater water potential drop upon a unit of cellular water lost and thus may lead to greater soil-to-leaf water potential gradients (Cheung et al. 1975; Kramer and Boyer 1995). Yet, whether an increase in $\varepsilon$ is indeed causing a $\Psi_{\text {leaf }}$ reduction large enough to enhance root water uptake depends mainly on the hydraulic conductivity of the root-to-leaf pathway (Bartlett et al. 2012), which is rarely measured in studies on elastic adjustment. The physiological role of increasing $\varepsilon$ is probably more related to the prevention of dehydration below a dangerous threshold $\left(\mathrm{RWC}_{\mathrm{tp}}\right)$ than to promoting soil water uptake (Bartlett et al. 2012). The time scale during which elastic adjustment occurs may also influence its function. Higher $\varepsilon$ values have been linked with greater foliar tissue density, i.e., thicker cell walls and lower proportional intercellular air spaces (Niklas 1991; Niinemets 2001). From experiments with droughtexposed Quercus seedlings, Saito and Terashima (2004) concluded that leaves developed under dry conditions possessed greater $\varepsilon$ than leaves developed under moist conditions, while $\varepsilon$ tended to decrease in mature leaves when they were exposed to drought. Accordingly, the direction of $\varepsilon$ change seems to depend on whether drought stress is imposed on developing or fully expanded mature leaves. All five species of our study are enfolding their foliage mostly during a single flush in spring, and most leaves remain active until approaching senescence in autumn. They are not replaced later in summer by subsequent leaf generations, as is the case, for example, in Betula. Thus, in our species, elastic adjustment is only possible in the existing leaves through reversible change in the molecular conformation of the cellulose microfibrils and the polysaccharide molecules of the cell wall matrix, and not by producing new leaves with adapted cell wall properties (Joly and Zaerr 1987). This may suggest that the potential for elastic adjustment is limited in single-flush species as investigated here.

\subsection{Different leaf-level strategies to cope with water deficits}

An unexpected result is the high cell wall elasticity of the T. cordata sun leaves, which have low solute concentrations in the symplast (high $\pi_{\text {tlp }}$ and $\pi_{0}$ ), but a relatively low $\mathrm{RWC}_{\text {tlp }}$ value, compared to the other four species. Little-leaved linden has a relatively hygromorphic leaf morphology at full hydration (high water content per dry mass at saturation and high specific leaf area (SLA)), associated with a high maximum leaf conductance and mass-related photosynthetic rate (Köcher et al. 2009; Leuschner and Ellenberg 2017). Due to its elastic leaves, the species can tolerate larger foliar water losses until zero turgor is reached than other species. Field observations in European Tilia species ( $T$. cordata, but more pronounced in Tilia platyphyllos and T. tomentosa; C. Leuschner, unpublished) indicate that $\mathrm{RWC}_{\text {tlp }}$ may well be exceeded in summer periods of high evaporative demand, resulting in reversible wilting. 
However, even in $T$. cordata, the observed $\mathrm{RWC}_{\text {tlp }}(0.81)$ was far above the threshold of 0.6 , below which dehydration is assumed to inhibit metabolism (Lawlor and Cornic 2002). This may explain why the wilting in $T$. cordata typically does not lead to pre-senescent leaf abscission.

Due to the relatively high $\pi_{\text {tpp }}$ value of $T$. cordata, midday $\Psi_{\text {min }}$ values did not drop below $-2 \mathrm{MPa}$, which is only topped by A. pseudoplatanus (>-1.0 MPa) in our sample. High $\pi_{\text {tpp }}$ values are thought to indicate low drought tolerance sensu Levitt, because the soil-to-plant potential gradient is generally smaller and leaf conductance, hydraulic conductance, photosynthesis, and growth should be reduced at higher water potentials than in plants maintaining lower $\pi_{\text {tlp }}$ (Bartlett et al. 2012). The example of T. cordata demonstrates that a tree can respond to drought with other strategies than decreasing $\pi_{\text {tlp }}$. According to dendroecological and ecophysiological studies, T. cordata behaves more like a water-spending, drought-avoiding species (Aasamaa et al. 2004; Köcher et al. 2009), which is able to consume relatively large amounts of water even during mild droughts (Gebauer et al. 2012) and is able to survive in the continental east of Europe and Western Russia. One explanation for this behavior could be that $T$. cordata invests more in fine root growth than the other species of this mixed stand (Jacob et al. 2014), which may help to maintain root water uptake during dry spells.

A different drought response strategy is found in ringporous $F$. excelsior, which has a moderate cell wall elasticity (about $22 \mathrm{MPa}$ ) and low $\pi_{\text {tlp }}$ and $\pi_{0}$ values. These properties allow ash to decrease midday leaf water potential to lower values than observed in any of the competing species $(<-$ 3.3 MPa), which enables the species to maintain water extraction in drying soil (Köcher et al. 2009). Carlier et al. (1992) found ash to keep stomates open even to pre-dawn leaf water potentials near $-5 \mathrm{MPa}$. F. excelsior showed a moderate increase in $\varepsilon$ during the summer, which increases the species' ability to reduce $\Psi_{1}$ in drought periods, but the species has also been found to accumulate osmotic compounds (mostly malate and mannitol) upon drought stress (Guicherd et al. 1997).

A third strategy type is pursued by $F$. sylvatica which combines in its sun leaves a relatively low $\pi_{\text {tpp }}$ value $(\sim-2.5 \mathrm{MPa})$ with a very high $\varepsilon$ value (around $30 \mathrm{MPa}$ ) and an apparent ability for elastic and osmotic adjustment upon drought. Significant elastic adjustment was also observed in Japanese Fagus species (Uemura et al. 2000), while osmotic adjustment was insignificant in a F. sylvatica stand in Northern Germany (Backes and Leuschner 2000), suggesting that the extent of osmotic adjustment (and perhaps also elastic adjustment) may largely depend on environmental conditions. Already small water losses decrease $\Psi_{1}$ in beech toward the turgor loss point with the consequence that midday $\Psi_{\min }$ reaches relatively low values in this species (up to $3 \mathrm{MPa}) . \mathrm{RWC}_{\mathrm{ttp}}$ is thus higher in beech (0.9) than in any other of the five species, which may be one reason for the relatively high drought sensitivity of radial growth in $F$. sylvatica compared to the other species (Zimmermann et al. 2015).
A. pseudoplatanus maintained relatively high $\pi_{\text {tlp }}$ and $\pi_{0}$, while cell wall elasticity was in the mid-range of $\varepsilon$ values measured here, associated with a comparably low apoplastic water fraction. Maple was the species with the smallest drop in midday $\Psi_{1}$ of all species (always $>-1 \mathrm{MPa}$ in 2008), which may relate to the relatively small solute concentration in the leaf symplast, but it is more likely caused by a high whole-tree hydraulic conductance (Köcher et al. 2009). Finally, $C$. betulus was, in most $\mathrm{p}-\mathrm{v}$ curve traits, intermediate between A. pseudoplatanus and F. sylvatica.

\section{Conclusions}

Even though our species sample is small, it includes species with a largely different leaf morphology (hygromorphic to mesomorphic leaves with highly variable SLA) and contrasting elastic properties, and it covered the full range of stomatal control strategies along the isohydry-anisohydry continuum. As a consequence, the species have developed alternative strategies to cope with the threat of desiccation (hypothesis i). Neither $\pi_{\text {tlp }}$ nor $\varepsilon$ was closely related to the stringency of stomatal control (isohydry/anisohydry; hypothesis ii), which is in line with the conclusion of Martinez-Vilalta and Garcia-Forner (2017) that isohydry/anisohydry is more related to xylem embolism resistance than to leaf water potential regulation. With respect to the drought sensitivity of growth as a measure of fitness under water deficit, the example of $F$. sylvatica shows that species with anisohydric stomatal regulation and tolerance of low $\Psi_{1}$ are not necessarily more successful than isohydric taxa (hypothesis iii). This suggests that studies combining leaf-level $\mathrm{p}-\mathrm{v}$ characteristics with analyses of stomatal regulation and hydraulic architecture, root system efficiency, and growth measurements are needed to fully understand the drought response strategy of adult trees.

Acknowledgments The authors thank the Hainich National Park administration for the fruitful cooperation and the granting of research permits.

Author contribution C.L. had the idea and developed together with P.W. the study design, P.W. conducted the measurements and the main data analysis, T.L. and C.L. conducted the additional statistical tests, and C.L. wrote the paper. All authors approved the final version of the manuscript.

Funding This study received financial support from DFG (Deutsche Forschungsgemeinschaft) in the context of Graduiertenkolleg 1086 through a grant to C.L; this support is gratefully acknowledged.

Data availability The data sets generated and/or analyzed during the current study are available from the corresponding author on reasonable request.

\section{Compliance with ethical standards}

Conflict of interest The authors declare that they have no conflict of interests. 


\section{Appendix}

Fig. 4 a Mean saturation water content (g water per g dry mass). b Mean relative water content at the turgor loss point $\left(\mathrm{RWC}_{\mathrm{tlp}}\right)$. $\mathbf{c}$ Mean symplastic water fraction at full turgor in sun leaves and shoots of the five tree species. Each bar represents the mean value $\pm \mathrm{SE}$ of three to four trees per species. Different capital letters indicate significant differences between tree species $(p<0.05)$
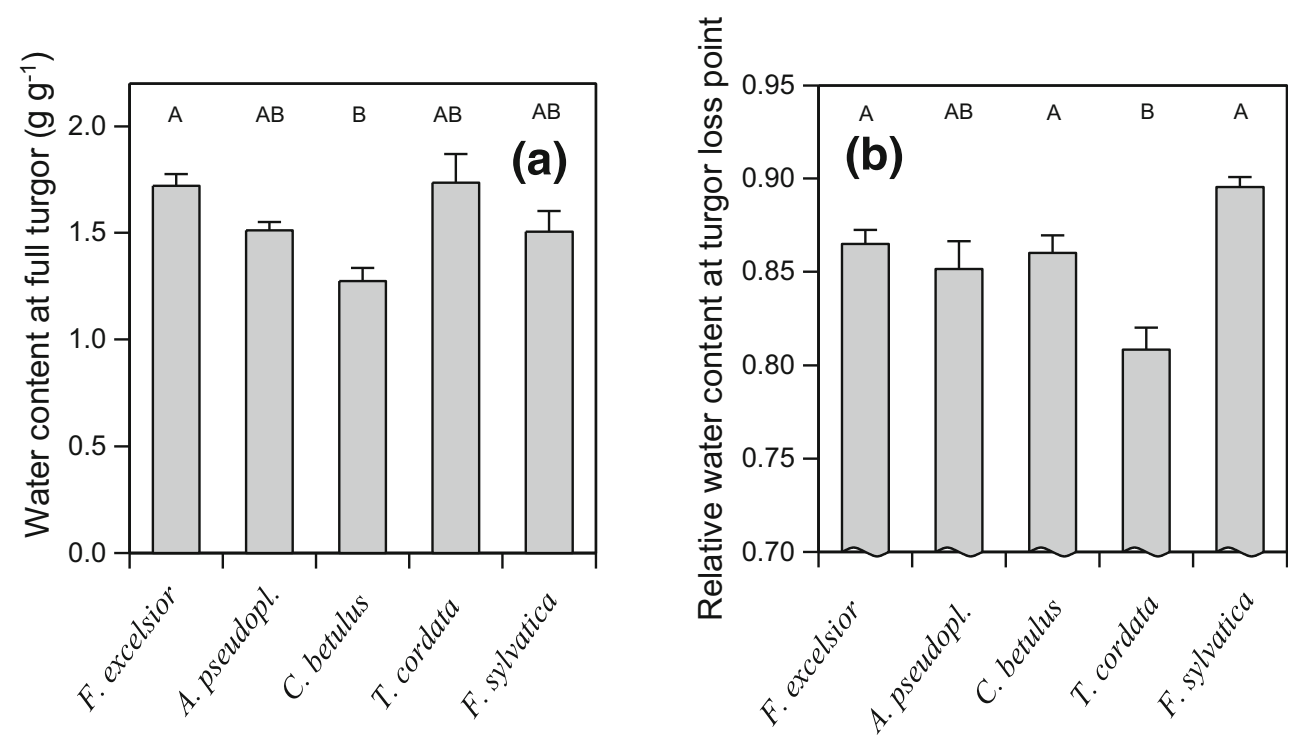


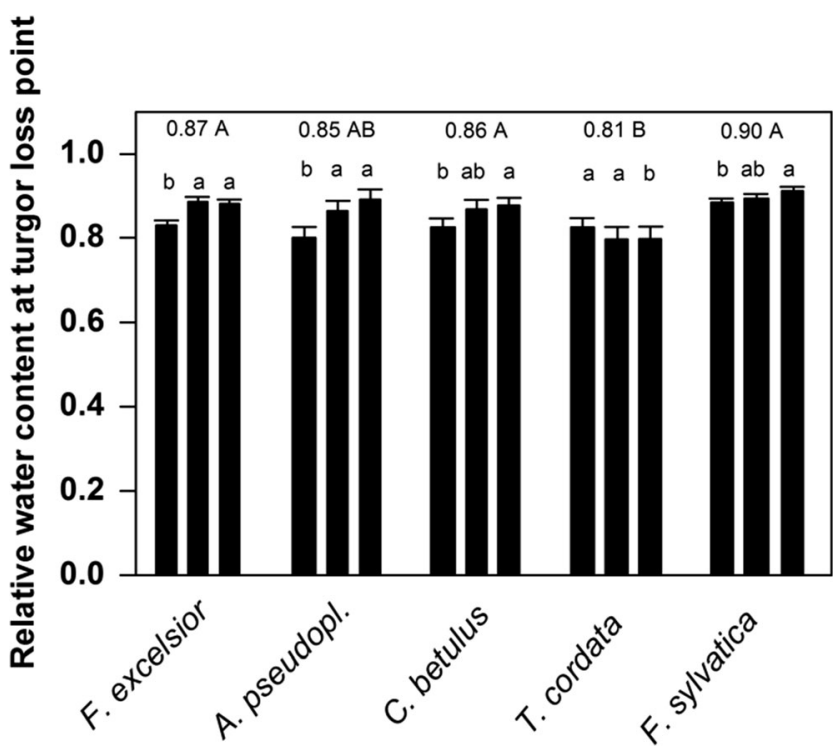

Fig. 5 Relative water content at turgor loss point $\left(\mathrm{RWC}_{\text {tlp }}\right)$ in sun leaves and shoots of the five tree species in June/July, August, and September. Each bar represents the mean value $\pm \mathrm{SE}$ of three to four trees per species. Different small letters indicate significant differences between periods (June/July, August, and September). Different capital letters indicate significant differences between tree species $(p<0.05)$

\section{References}

Aasamaa K, Söber A, Hartung W, Niinemets Ü (2004) Drought acclimation of two deciduous tree species of different layers in a temperate forest canopy. Trees 18:93-101

Abrams MD (1988) Genetic variation in leaf morphology and plant and tissue water relations during drought in Cercis canadensis L. For Sci 34:200-207

Abrams MD (1991) Adaptations and responses to drought in Quercus species of North America. Tree Physiol 7:227-238

Abrams MD, Kubiske ME (1990) Photosynthesis and water relations during drought in Acer rubrum L. genotypes from contrasting sites in Central Pennsylvania. Funct Ecol 4:727-733

Allen CD, Macalady AK, Chenchouni H, Bachelet D, McDowell N, Vennetier M, Kitzberger T, Rigling A, Breshears DD, Hogg EH(T), Gonzalez P, Fensham R, Zhang Z, Castro J, Demidova N, Lim JH, Allard G, Running SW, Semerci A, Cobb N (2010) A global overview of drought and heat-induced tree mortality reveals emerging climate change risks for forests. For Ecol Manag 259:660 684

Backes K, Leuschner C (2000) Leaf water relations of competitive F. sylvatica sylvatica L. and Quercus petraea (Matt.) Liebl. trees during four years differing in soil drought. Can J For Res 30:335-346

Baltzer JL, Davies SJ, Bunyavejchewin S, Noor SSM (2008) The role of desiccation tolerance in determining tree species distributions along the Malay-Thai Peninsula. Funct Ecol 22:221-231

Bartlett MK, Scoffoni C, Sack L (2012) The determinants of leaf turgor loss point and prediction of drought tolerance of species and biomes: a global meta-analysis. Ecol Lett 15:393-405

Blackman CJ, Brodribb TJ, Jordan GJ (2010) Leaf hydraulic vulnerability is related to conduit dimensions and drought resistance across a diverse range of woody angiosperms. New Phytol 188:1113-1123

Blum A (2016) Stress, strain, signaling, and adaptation — not just a matter of definition. J Exp Bot 67:563-566

Bréda N, Huc R, Granier A, Dreyer E (2006) Temperate forest trees and stands under severe drought: a review of ecophysiological responses, adaptation processes and long-term consequences. Ann For Sci 63:625-644

Brodribb TJ, McAdam SAM, Jordan GJ, Martins SCV (2014) Conifer species adapt to low-rainfall climates by following one of two divergent pathways. Proc Natl Acad Sci U S A 111:14489-14493

Carlier G, Peltier JP, Gielly L (1992) Comportement hydrique du frêne (F. excelsior excelsior L.) dans une formation montagnarde mésoxérophile. Ann Sci For 49:207-223

Cavender-Bares J, Bazzaz FA (2000) Changes in drought response strategies with ontogeny in Quercus rubra: implications for scaling from seedlings to mature trees. Oecologia 124:8-18

Cheung YNS, Tyree MT, Dainty J (1975) Water relations parameters on single leaves obtained in a pressure bomb and some ecological interpretations. Can J Bot 53:1342-1346

Choat B, Jansen S, Brodribb TJ, Cochard H, Delzon S, Bhaskar R, Bucci SJ, Feild TS, Gleason SM, Hacke UG, Jacobsen AL, Lens F, Maherali H, Martínez-Vilalta J, Mayr S, Mencuccini M, Mitchell PJ, Nardini A, Pittermann J, Pratt RB, Sperry JS, Westoby M, Wright IJ, Zanne AE (2012) Global convergence in the vulnerability of forests to drought. Nature 491:752-755

Clifford SC, Arndt SK, Corlett JE, Joshi S, Sankhla M, Jones HG (1998) The role of solute accumulation, osmotic adjustment and changes in cell wall elasticity in drought tolerance of Ziziphus mauritiana (Lamk). J Exp Bot 49:967-977

Corcuera L, Camarero JJ, Gil-Pelegrin E (2002) Functional groups in Quercus species derived from the analysis of pressure-volume curves. Trees 16:465-472

Dreyer E, Bousquet F, Ducrey M (1990) Use of pressure volume curves in water relation analysis on woody shoots: influence of rehydration and comparison of four European oak species. Ann Sci For 47:285297

Ellenberg H (1996) Vegetation Mitteleuropas mit den Alpen, 5th edn. Ulmer, Stuttgart

Fan S, Blake TJ, Blumwald E (1994) The relative contribution of elastic and osmotic adjustments to turgor maintenance of woody species. Physiol Plant 90:408-413

Gebauer T, Horna V, Leuschner C (2008) Variability in radial sap flux density patterns and sapwood area among seven co-occurring temperate broad-leaved tree species. Tree Physiol 28:1821-1830

Gebauer T, Horna V, Leuschner C (2012) Canopy transpiration of pure and mixed forest stands with variable abundance of European beech. J Hydrol 442-443:2-14

Gessler A, Keitel C, Kreuzwieser J, Matyssek R, Seiler W, Rennenberg H (2007) Potential risk for European beech (F. sylvatica sylvatica L.) in a changing climate. Trees 21:1-11

Guckland A, Jacob M, Flessa H, Thomas FM, Leuschner C (2009) Acidity, nutrient stocks and organic-matter content in soils of temperate deciduous forest with different abundance of European beech (F. sylvatica sylvatica L.). J Plant Nutr Soil Sci 172:500-511

Guicherd P, Peltier JP, Gout E, Bligny R, Marigo G (1997) Osmotic adjustment in F. excelsior excelsior L.: malate and mannitol accumulation in leaves under drought conditions. Trees 11:155-161

Hiekel W, Fritzlar F, Nöllert A, Westhus W (2004) Die Naturräume Thüringens. Naturschutzreport (Jena) 21:6-381

Hinckley TM, Teskey RO, Duhme F, Richter H (1981) Temperate hardwood forests. In: Kozlowski TT (ed) Water deficits and plant growth, Woody plant communities, vol VI. Academic, New York, pp 153-208

Hsiao TC (1973) Plant responses to water stress. Ann Rev Plant Physiol Mol Biol 24:519-570

IPCC (2013) Climate change 2013: the physical science basis. In: Stocker TF et al (eds) Contribution of working group I to the fifth assessment report of the intergovernmental panel on climate change. Cambridge University Press, UK and New York, 1535 pp 
Jacob A, Hertel D, Leuschner C (2014) Diversity and species identity effects on fine root productivity and turnover in a species-rich temperate broad-leaved forest. Funct Plant Biol 41:678-789

Joly RJ, Zaerr JB (1987) Alteration of cell-wall water content and elasticity in Douglas-fir during periods of water deficit. Plant Physiol 83: 418-422

Khalil AAM, Grace J (1992) Acclimation to drought in A. pseudoplatanus pseudoplatanus L. (Sycamore) seedlings. J Exp Bot 43:1591-1602

Klein T (2014) The variability of stomatal sensitivity to leaf water potential across tree species indicates a continuum between isohydric and anisohydric behaviours. Funct Ecol 28:1313-1320

Knutzen F, Meier IC, Leuschner C (2015) Does reduced precipitation trigger physiological and morphological drought adaptations in European beech (F. sylvatica sylvatica L.)? Comparing provenances across a precipitation gradient. Tree Physiol 35:949-963

Köcher P, Gebauer T, Horna V, Leuschner C (2009) Leaf water status and stem xylem flux in relation to soil drought in five temperate broadleaved tree species with contrasting water use strategies. Ann For Sci 66:101-112

Köcher P, Horna V, Leuschner C (2012a) Environmental control of daily stem growth patterns in five temperate broad-leaved tree species. Tree Physiol 32:1021-1032

Köcher P, Horna V, Beckmeyer I, Leuschner C (2012b) Hydraulic properties and embolism in small-diameter roots of five temperate broadleaved tree species with contrasting drought tolerance. Ann For Sci 69:693-703

Koide RT, Robichaux RH, Morse RH, Smith CM (2000) Plant water status, hydraulic resistance and capacitance. In: Pearcy RW, Ehleringer JR, Mooney HA, Rundel PW (eds) Plant physiological ecology: field methods and instrumentation. Kluwer, Dordrecht, pp 161-183

Kozlowski TT, Pallardy SG (2002) Acclimation and adaptive responses of woody plants to environmental stresses. Biol Rev 68:270-334

Kramer PJ, Boyer JS (1995) Water relations of plants and soils. Academic, San Diego

Kubiske ME, Abrams MD (1991) Rehydration effects on pressurevolume relationships in four temperate woody species: variability with site, time of season and drought conditions. Oecologia 85:537542

Kubiske ME, Abrams MD (1994) Ecophysiological analysis of woody species in contrasting temperate communities during wet and dry years. Oecologia 98:303-312

Lakatos F, Molnar M (2009) Mass mortality of beech (Fagus sylvatica L.) in south-west Hungary. Acta Silv Lign Hung 5:75-82

Lambers H, Chapin FS III, Pons TL (2008) Plant physiological ecology, 2nd edn. Springer, New York

Lenz TI, Wright IJ, Westoby M (2006) Interrelations among pressurevolume curve traits across species and water availability gradients. Physiol Plant 127:423-433

Leuschner C, Ellenberg H (2017) Ecology of Central European forests. Vegetation ecology of Central Europe, vol I. Springer Nature, Cham, $971 \mathrm{p}$

Leuschner C, Meier IC (2018) The ecology of Central European tree species: trait spectra, functional trade-offs, and ecological classification of adult trees. Perspect Plant Ecol Evol Syst 33:89-103. doi.org/ https://doi.org/10.1016/j.ppees.2018.05.003

Leuzinger S, Zotz G, Asshoff R, Körner C (2005) Responses of deciduous forest trees to severe drought. Tree Physiol 25:641-650

Levitt J (1972) Responses of plants to environmental stresses. Academic, New York

Lübbe T, Schuldt B, Leuschner C (2017) Acclimation of leaf water status and stem hydraulics to drought and tree neighbourhood: alternative strategies among the saplings of five temperate deciduous tree species. Tree Physiol 37:456-468
Martinez-Vilalta J, Garcia-Forner N (2017) Water potential regulation, stomatal behavior and hydraulic transport under drought: deconstructing the iso/anisohydric concept. Plant Cell Environ 40: 962-976

McDowell NG, Pockman WT, Allen CD, Breshears DD, Cobb N, Kolb T, Plaut J, Sperry J, West A, Williams DG, Yepez EA (2008) Mechanisms of plant survival and mortality during drought: why do some plants survive while other succumb to drought? New Phytol 178:719-739

Meinzer FR (2002) Coordination of vapor and liquid phase water transport properties in plants. Plant Cell Environ 25:265-274

Meinzer FC, Woodruff DR, Marias DE, McCulloh KA, Sevanto S (2014) Dynamics of leaf water relations components in co-occurring isoand anisohydric conifer species. Plant Cell Environ 37:2577-2586

Meinzer FC, Smith DD, Woodruff DR, Marias DE, McCulloh KA, Howard AR, Magedman AL (2017) Stomatal kinetics and photosynthetic gas exchange along a continuum of isohydric to anisohydric regulation of plant water status. Plant Cell Environ 40: $1618-1628$

Mencucchini M (2003) The ecological significance of long-distance water transport: short-term regulation, long-term acclimation and the hydraulic costs of stature across plant life forms. Plant Cell Environ 26:163-182

Merchant A (2014) The regulation of osmotic potential in trees. In: Tausz M, Grulke N (eds) Trees in a changing environment, Plant ecophysiology, vol 9. Springer, Dordrecht, pp 83-97

Mitchell PJ, Veneklaas EJ, Lambers H, Burgess SO (2008) Leaf water relations during summer water deficit: differential repsonses in turgor maintenance and variation in leaf structure among different plant communities in South-Western Australia. Plant Cell Environ 31: $1791-1802$

Ngugi M, Doley D, Hunt M, Dart P, Ryan P (2003) Leaf water relations of Eucalyptus cloeziana and Eucalyptus argophloia in response to water deficit. Tree Physiol 23:335-343

Niinemets Ü (2001) Global-scale climate controls of leaf dry mass per area, density and thickness in trees and shrubs. Ecology 82:453-469

Niklas KJ (1991) Biomechanical attributes of the leaves of pine species. Ann Bot 68:253-262

Osonubi O, Davies WJ (1978) Solute accumulation in leaves and roots of woody plants subjected to water stress. Oecologia 32:323-332

Pallardy SG (2008) Physiology of woody plants, 3rd edn. Elsevier, Amsterdam

Parker WC, Pallardy SG (1988) Leaf and root osmotic adjustment in drought-stressed Quercus alba, Q. macrocarpa, and Q. stellate seedlings. Can J For Res 18:1-5

Peltier J-P, Marigo G (1999) Drought adaptation in F. excelsior excelsior L.: physiological basis of the elastic adjustment. J Plant Physiol 154: 529-535

Pinheiro J, Bates D, DebRoy S, Sarkar D, R Core Team (2018) nlme: linear and nonlinear mixed effects models. R Package Version 3:1137 https://CRAN

Prometheuswiki (2018) Leaf pressure-volume curve parameters. http:// prometheuswiki.org/tiki-index.php?page=Pressure-volume+curves. (accessed 2/2018)

Saito T, Terashima I (2004) Reversible decreases in the bulk elastic modulus of mature leaves of deciduous Quercus species subjected to tow drought treatments. Plant Cell Environ 27:863-875

Sanders GJ, Arndt SK (2012) Osmotic adjustment under drought conditions. In: Aroca R (ed) Plant responses to drought stress. Springer, Berlin, Heidelberg, pp 199-229

Schaap MG, Leij FJ, van Genuchten MT (1998) Neural network analysis for hierarchical prediction of soil hydraulic properties. Soil Sci Soc Am J 62:847-855

Schuldt B, Knutzen F, Delzon S, Jansen S, Müller-Haubold H, Burlett R, Clough Y, Leuschner C (2016) How adaptable is the hydraulic 
system of European beech in the face of climate change-related precipitation reduction? New Phytol 210:443-458

Schulte PJ (1992) The units of currency for plant water status. Plant Cell Environ 15:7-10

Sheffield J, Wood EF (2008) Global trends and variability in soil moisture and drought characteristics, 1950-2000, from observation-driven simulations of the terrestrial hydrological cycle. J Clim 21:432-458

Sokal RR, Rohlf FJ (1995) Biometry. The principles and practice of statistics in biological research, 3rd edn. W. H. Freeman and Co, New York

Tardieu F, Simonneau T (1998) Variability among species of stomatal control under fluctuating soil water status and evaporative demand: modelling isohydric and anisohydric bahaviours. J Exp Bot 49:419432

Tschaplinski TJ, Blake TJ (1989) Water-stress tolerance and late-season organic solute accumulation in hybrid poplar. Can J Bot 67:16811688

Tyree MT, Jarvis PG (1982) Water in tissues and cells. Encyclopedia plant physiol. N.S., Vol. 12B. Springer, Berlin, pp 35-77

Uemura A, Ishida A, Nakano T, Terashima I, Tanabe H, Matsumoto Y (2000) Acclimation of leaf characteristics of F. sylvatica species to previous-year and current year solar irradiances. Tree Physiol 20: 945-951

Van Mantgem PJ, Stephenson NL, Byrne JC, Daniels LD, Franklin JF, Fulé PZ, Harmon ME et al (2009) Widespread increase of tree mortality rates in the western United States. Science 323:521-524

Williams CB, Naesborg RR, Dawson TE (2017) Coping with gravity: the foliar water relations of giant sequoia. Tree Physiol 37:1312-1326

Wright IJ, Westoby M (2002) Leaves at low versus high rainfall: coordination of structure, lifespan and physiology. New Phytol 155:403416

Zimmermann J, Hauck M, Dulamsuren C, Leuschner C (2015) Climate warming-related growth decline affects $\mathrm{F}$. sylvatica sylvatica, but not other broad-leaved tree species in Central European mixed forests. Ecosystems 18:560-572

Zuur A, Ieno EN, Walker N, Savaliev AA, Smith GM (2009) Mixed effects models and extensions in ecology with R. Springer Science

Publisher's note Springer Nature remains neutral with regard to jurisdictional claims in published maps and institutional affiliations. 